\title{
The Investigation of Entamoeba histolytica Prevalence in Some Villages of Sivas by ELISA Method
}

\author{
Sivas’ın Bazı Köylerinde Entamoeba histolytica Yaygınlığının Elisa Yöntemiyle Araştırılması
}

\author{
Erdoğan Malatyalı, Semra Özçelik, Ali Çeliksöz \\ Cumhuriyet Üniversitesi Tıp Fakültesi, Parazitoloji Anabilim Dalı, Sivas, Turkey
}

\begin{abstract}
Objective: Humans may be infected with three morphologically identical Entamoeba species; pathogenic E. histolytica, commensal E. moshkowskii and E. dispar. The aim of the present study was to determine the true prevalence of the E. histolytica using native lugol, trichrome staining and a monoclonal antigen detection kit (ELISA kit E. histolytica-II; Techlab, Inc., Blacksburg, VA) among primary school children living in the rural areas around Sivas.

Methods: A total of 1449 stool samples were examined by native lugol and Trichrome staining, and 312 (22\%) samples were positive for one or more parasite species. Additionally, $22(1.5 \%)$ stool samples were found to be positive for the presence of E. histolytica/dispar cysts, and these samples were further examined by E. histolytica specific antigen based ELISA.

Results: As a result, ELISA test gave negative reactions for all the samples. Also, there was no cross reaction with other luminal protozoa such as E. coli, G. intestinalis, B. hominis and I. butschlii.

Conclusion: The data reveals that E. histolytica prevalence may be lower than estimated. (Turkiye Parazitol Derg 2011; 35: 6-9)

Key Words: ELISA, Entamoeba histolytica, prevalence
\end{abstract}

Received: 29.07.2010 Accepted: 09.02.2011

\section{ÖZET}

Amaç: Insanlar morfolojik olarak ayırt edilemeyen patojenik E. histolytica ve kommensal E. moshkowskii ve E. dispar türleriyle enfekte olabilir. Bu çalışmanın amacı, Sivas'ın bazı köylerinde yaşayan öğrencilerde monoklonal antijen kitiyle (E. histolytica-II; Techlab, Inc., Blacksburg, VA) E. histolytica'nın yaygınlığını saptamaktır.

Yöntemler: Bu amaçla toplanan 1449 dışkı örneğinin direkt mikroskobik incelenmesi (nativ lugol ve Trikrom) sonucu 312 (\%22)'sinde bir veya daha fazla bağırsak parazitine rastlanmıştır. Ayrıca E. histolytica/dispar kisti saptanan 22 (\%1.5) dışkı örneği ELISA ile E. histolytica varlığı yönünden araştırılmıştır.

Bulgular: Sonuç olarak E. histolytica/dispar kisti saptanan örneklerin tamamının ELISA testi ile negatif sonuç verdiği gözlenmiş, bununla birlikte antijen testinin diğer bağırsak protozoonlarıyla (E. coli, G. intestinalis, B. hominis ve I. butschlii) çapraz reaksiyon vermediği belirlenmiştir. Sonuç: Elde edilen bulgular bölgemizde E. histolytica yaygınlığının tahmin edilenden daha az olabileceğini ortaya koymaktadır.

(Turkiye Parazitol Derg 2011; 35: 6-9)

Anahtar Sözcükler: ELISA, Entamoeba histolytica, prevelans

Geliş Tarihi: 29.07.2010

Kabul Tarihi: 09.02.2011

\section{INTRODUCTION}

Entamoeba histolytica is the causative agent of amebiasis that results in dysentery or amebic abscess (1). This infectious agent is known to be common in developing areas; although cases have been described in developed countries among homosexual men, immigrants, HIV infected patients and travelers visiting endemic areas $(2,3)$. Following malaria and schistosomiasis, amebiasis is the third leading cause of death among parasitic diseases on a global scale; it affects approximately 50 million people each year, resulting in almost 100.000 deaths (4). However, the true distribution of the disease is not clear in most of the countries. This has been particularly complicated by the existence of different species morphologically identical but genetically differ-

Address for Correspondence/ Yazışma Adresi: Dr. Erdoğan Malatyalı, Cumhuriyet Üniversitesi Tıp Fakültesi, Parazitoloji Anabilim Dalı, Sivas, Turkey Phone: +90 34621910 10-1044 E-mail: emalatyali@cumhuriyet.edu.tr doi:10.5152/tpd.2011.02 
ent; namely E. histolytica, which is pathogenic, E.moshkowskii and E. dispar, which are non-pathogenic species (5). The differentiation of $E$. histolytica and $E$. dispar is necessary to avoid unnecessary treatment of patients infected with the non-pathogenic E. dispar and to estimate the real prevalence of E. histolytica (6). Currently, microscopy, immunoflorescence (IFA), polymerase chain reaction (PCR) and serological methods including enzyme-linked immunosorbent assay (ELISA), indirect hemagglutination assay (IHA), and latex agglutination are used for the laboratory diagnosis of amebiasis (7). The diagnosis of intestinal amoebiasis is still mostly based on the microscopical detection of organisms in stool samples (8). The disadvantages of microscopy are that it requires a skilled microscopist and has low sensitivity and specifity compared with other methods, such as IFA, antigen detection, and PCR (9). Unfortunately, PCR based methods are still too complicated and expensive for the public health systems of many communities (10). Very few studies have addressed the true incidence and prevalence of $E$. histolytica and $E$. dispar in rural areas. Recent epidemiological surveys have shown that the prevalence of E. histolytica/dispar varies between $0.5 \%$ and $7.8 \%$ in the Sivas province $(11,12)$.

The aim of the study was to determine the prevalence of E. histolytica in children in some villages of Sivas, by a monoclonal antigen detection kit.

\section{MATERIALS AND METHODS}

Stool samples were collected from children in the rural areas in the Sivas province during 2008. The study group includes 1449 children educated in six different schools (Karşıyaka, Ahmet Türkseven, Kurtlapa, Demirçelik, Gürçayır Kenan Evren and Cumhuriyet Primary Schools). The schools were selected by the simple random sampling method. A questionnaire was completed with the details of every child. The observations were performed with the aid of the school teacher and the parents were informed about the application and also the required permissions were acquired from Sivas Governorship.

Stool samples were investigated by native-lugol examination and Gomori's Trichrome staining (13). The presence of E. histo- lytica-specific galactose adhesin was determined with a commercially available kit (ELISA kit E. histolytica-II; Techlab, Inc., Blacksburg, VA) among the samples positive for the presence of one-four-nuclei amoeba. Fresh samples were used for the assay. All stool samples were examined by ELISA on the same day without prior preservation. Additionally, stool samples that contain other protozoa cysts were also investigated with the same kit. The positive result was determined according to the manufacturer's instructions, an optical density reading $>0.05$ after subtraction of the negative control optical density.

\section{RESULTS}

In the present study, stool samples were collected from 1499 children to determine the prevalence of E. histolytica. E. histolytica/dispar cyst form was detected in 22 (1.5\%) stool samples by native-lugol examination and Trichrome staining. The overall infection rate of intestinal parasitic infection was $22 \%$ among the children. In addition, the most frequent parasite species were $G$. intestinalis (10.4\%), E. coli (8.8\%) and E. vermicularis (7.7\%), respectively. 782 (54\%) of children were female and 667 (46\%) were male. The infection rate among females was $1.8 \%$ which was not significantly higher than that among males $1.2 \%$. $\left(\chi^{2}=0.84, p>0.05\right)$ (Table 1).

The children's ages varied from 6 to 15 years. No significant difference was found between the two age groups (6-9 and 10-15) according to the prevalence of $E$. histolytica/dispar $\left(\chi^{2}=0.44, p>0.05\right)$ (Table 2). Moreover, it was found that the school success level was not associated with the parasite infection rate $\left(\chi^{2}: 7.59, p>0.05\right)$ (Table 3$)$. Regarding the monthly income of the children, the results revealed that the rate of $E$. histolytica/dispar infection among those with low incomes (2.3\%) was significantly different from that among those with high income $\left(\chi^{2}: 6.91, p<0.05\right)$ (Table 4$)$. The clinical features of children are documented in Table 6 . Of 22 cyst passengers, 6 (27.3\%) had abdominal pain according to the survey. There was no statistically significant difference for abdominal pain between the children who were four nuclei cysts passengers and others $\left(\chi^{2}: 6.40, p>0.05\right)$.

Table 1. The rate of E. histolytica/dispar infection according to gender

\begin{tabular}{|l|c|c|c|c|c|c|}
\hline \multirow{2}{*}{ E. histolytica/dispar } & \multicolumn{2}{|c|}{ Female } & \multicolumn{2}{c|}{ Male } & \multicolumn{2}{c|}{ Total } \\
\cline { 2 - 7 } & $\mathbf{n}$ & $\%$ & $\mathbf{n}$ & $\%$ & $\mathbf{n}$ & \% \\
\hline Cysts (+) & 8 & 1.2 & 14 & 1.8 & 1.5 \\
\hline Cysts (-) & 659 & 98.8 & 1.8 & 98.2 & 1427 & 98.5 \\
\hline Total & 667 & 46 & 782 & 54 & 1449 & 100 \\
\hline
\end{tabular}

Table 2. The rate of E. histolytica/dispar infection according to age groups

\begin{tabular}{|l|c|c|c|c|c|}
\hline \multirow{2}{*}{ E. histolytica/dispar } & \multicolumn{2}{|c|}{ Younger } & \multicolumn{2}{c|}{ Older } & \multicolumn{2}{c|}{ Total } \\
\cline { 2 - 7 } & $\mathbf{n}$ & $\%$ & $\mathbf{n}$ & $\%$ & $\mathbf{n}$ \\
\hline Cysts (+) & 7 & 1.2 & 15 & 1.7 & 22 \\
\hline Cysts (-) & 554 & 98.8 & 873 & 98.3 & 1427 \\
\hline Total & 561 & 38.7 & 888 & 61.3 & 1449 \\
\hline
\end{tabular}


A total of 86 stool samples that contain protozoa cysts (E. histolytica/dispar, E. coli, B. hominis, G. intestinalis, I. butschlii) and 2 negative controls were tested for the pathogenic strain by ELISA (Table 5). All 88 samples were negative in the ELISA for the presence of $E$. histolytica-specific galactose adhesin. However, when we also studied a pathogenic strain of E. histolytica was cultured in our laboratuary, and it gave positive reaction in antigen test.

\section{DISCUSSION}

Our findings are consistent with those previously reported in neighboring cities. The prevalence of E. histolytica/dispar complex is reported to be between $0 \%$ and $17.4 \%$ in these region by microscopical detection $(14,15)$. Microscopical detection of the organisms in stool is time and labour intensive and depends on the skill of an experienced microscopist $(16,17)$. Also, it is impossible to distinguish nonpathogenic E. dispar (morphological identical) from E. histolytica. The presence of E. histolytica in stool specimens can be considered only when erythrocytes are observed within trophozoites (18). The sensitivity and selectivity of direct microscopy is reported as 5\%-60\% and 10\%-50\%, respectively (7). The diagnosis of parasites with clinical symptoms is difficult. Because, the majority of infected individuals are asymptomatic, even with E. histolytica; only 5-10\% develop diarrhea or colitis and a smaller subset develop extra intestinal disease, mainly amebic liver abscess (19). A record is available that indicates that $E$. histolytica is more common than E. dispar in Zonguldak. Mengeloglu et al. reported that $59.1 \%$ of four nuclei cysts was positive by ELISA (Seramun Diagnostica GmbH, Wolzig, Germany) among people with gastrointestinal complaints (20). In the present study, most of the children in the experimental group (cyst passengers) were not suffering from abdominal pain, which supports the outcome of the study. The reason for the difference between results obtained by the present study, and the Mengeloglu et al. study reveals that people with gastrointestinal symptoms have to be tested for $E$. histolytica surface adhesins for a reliable diagnosis.

Table 3. The rate of E. histolytica/dispar infection according to school success

\begin{tabular}{|c|c|c|c|c|c|c|c|c|c|c|}
\hline \multirow[b]{2}{*}{ E. histolytica/dispar } & \multicolumn{2}{|c|}{1} & \multicolumn{2}{|c|}{2} & \multicolumn{2}{|c|}{3} & \multicolumn{2}{|c|}{4} & \multicolumn{2}{|c|}{5} \\
\hline & $\mathbf{n}$ & $\%$ & $\mathrm{n}$ & $\%$ & $\mathrm{n}$ & $\%$ & $\mathrm{n}$ & $\%$ & $\mathrm{n}$ & $\%$ \\
\hline Cysts (+) & 3 & 3.9 & 4 & 2.6 & 7 & 1.6 & 6 & 1.8 & 22 & 1.5 \\
\hline Total & 76 & 5.2 & 156 & 10.7 & 447 & 30.8 & 334 & 23.0 & 1449 & 100 \\
\hline
\end{tabular}

Table 4. The rate of E. histolytica/dispar infection according to socio-economical level

\begin{tabular}{|l|c|c|c|c|c|c|c|c|}
\hline \multirow{2}{*}{ E. histolytica/dispar } & \multicolumn{2}{|c|}{ Low income } & \multicolumn{2}{c|}{ Avarage income } & \multicolumn{2}{c|}{ High income } & \multicolumn{2}{c|}{ Total } \\
\cline { 2 - 10 } & $\mathbf{n}$ & $\%$ & $\mathbf{n}$ & $\%$ & $\mathbf{n}$ & $\%$ & $\mathbf{n}$ & $\%$ \\
\hline Cysts (+) & 16 & 2.3 & 6 & 1.1 & 0 & 0 & 22 & 1.5 \\
\hline Cysts (-) & 670 & 97.7 & 555 & 98.9 & 202 & 100 & 1427 & 98.5 \\
\hline Total & 686 & 47.3 & 561 & 38.7 & 202 & 13.9 & 1449 & 100 \\
\hline
\end{tabular}

Table 5. Distribution of the clinical features of children

\begin{tabular}{|l|c|c|c|c|c|c|}
\hline \multirow{2}{*}{ E. histolytica/dispar } & \multicolumn{2}{|c|}{ Abdominal pain } & \multicolumn{2}{|c|}{ Gnashing } & \multicolumn{2}{c|}{ Extensive salivation } \\
\cline { 2 - 7 } & $\mathbf{n}$ & $\%$ & $\mathbf{n}$ & $\mathbf{0}$ & $\mathbf{n}$ & $\%$ \\
\hline Cysts (+) & 6 & 27.3 & 4 & 18.2 & 3 & 13.6 \\
\hline Cysts (-) & 481 & 33.7 & 165 & 11.6 & 235 & 16.5 \\
\hline Total & 487 & 33.6 & 169 & 11.7 & 238 & 16.4 \\
\hline
\end{tabular}

Table 6. Distribution of parasites in samples used for immunoenzymatic assay

\begin{tabular}{|c|c|c|c|c|c|c|c|c|c|c|}
\hline & 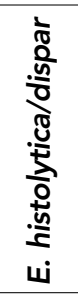 & $\begin{array}{l}\overline{8} \\
\end{array}$ & 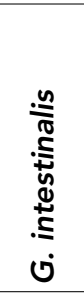 & 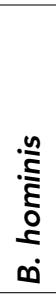 & 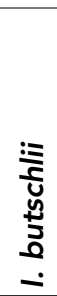 & 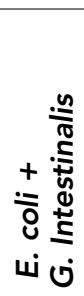 & 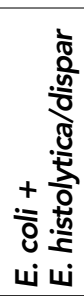 & 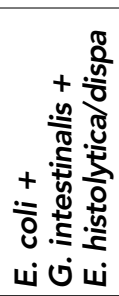 & 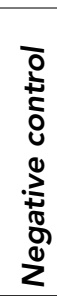 & $\begin{array}{l}\bar{\pi} \\
\stackrel{0}{0} \\
\end{array}$ \\
\hline Number & 14 & 38 & 11 & 3 & 6 & 7 & 5 & 2 & 2 & 88 \\
\hline$\%$ & 15.9 & 43.2 & 12.5 & 3.4 & 6.8 & 7.9 & 5.7 & 2.3 & 2.3 & 100 \\
\hline
\end{tabular}


PCR, izoenzyme assays and serologic tests can be used for the differentiation of E. histolytica and E. dispar (16). Antigen detection methods were reported as a better diagnostic tool than the antibody detection (21). Furthermore, recently developed antigen detection methods such as Tech-Lab ELISA were shown to be a sensitive and specific method for the rapid differentiation of the two species because it is easy to perform and entails low cost compared to others (8). In this study, the entire four nuclei cysts showed no E. histolytica pattern. These are thought to be other identical amoebas like E. dispar and E. moshkowskii. Some records are available that show the occurrence of these organisms in our country, but no data has been found in this region $(4,22-24$, 26). No cross reaction was detected with other luminal protozoa (E. histolytica/dispar, E. coli, B. hominis, G. intestinalis, I. butschlii) as previously reported (25). Our study indicates that E.dispar may be more common in our region than in other countries (26). Recent data point out that $E$. dispar is perhaps 7-10 times more common than E. histolytica worldwide (27).

The frequencies of $E$. histolytica using the Tech Lab antigen detection kit were reported as $15.6 \%$ in Egypt among symptomatic group and as $8 \%$ in Bangladesh among the asymptomatic group $(28,29)$. Amoebiasis is common in tropical and developing countries due to poor sanitary conditions (24). In the present study, the number of four nuclei cyst passengers was high in the group with low incomes which emphasises that status and specific socioeconomic levels influence the parasite distribution. In conclusion, direct microscopic diagnosis of amebiasis is not an efficient method for the diagnosis of E. histolytica, so we recommend that ELISA procedures based on reliable antigens such as surface adhesins can be used in this region as in other parts of the world.

\section{Conflict of Interest}

No conflict of interest is declared by the authors.

\section{REFERENCES}

1. John DT, Petri WA. Markell and Voge's Medical Parasitology. 8th ed. London: WB Saunders Company 2006; p. 22-35.

2. Lowther SA, Dworkin MS, Hanson DL. Entamoeba histolytica/ Entamoeba dispar infections in human immunodeficiency virusinfected patients in the United States. Clin Infect Dis 2000; 30: 955-9. [CrossRef]

3. Ohnishi K, Murata M, Okuzawa E. Symptomatic amebic colitis in a Japanese homosexual AIDS patient. Intern Med 1994; 33: 120-2. [CrossRef]

4. Walsh JA. Problems in recognition and diagnosis of amebiasis: estimation of the global magnitude of morbidity and mortality. Rev Infect Dis 1986; 8: 228-38. [CrossRef]

5. Diamond LS, Clark CG. A redescription of Entamoeba histolytica Schaudinn. 1903 (Emended Walker, 1911), separating it from Entamoeba dispar Brumpt, 1925. J Eukaryot Microbiol 1993; 40: 340-4. [CrossRef]

6. Tanyuksel M, Petri WA. Laboratory diagnosis of amebiasis. Clin Microbiol Rev 2003; 16: 713-29. [CrossRef]

7. Petri WA, Haque R, Lyerly D, Vines RR. Estimating the impact of amebiasis on health. Parasitol Today 2000; 16: 320-1. [CrossRef]

8. Schunk M, Jelinek T, Wetzel K, Nothdurft HD. Detection of Giardia lamblia and Entamoeba histolytica in stool samples by two enzyme immunoassays. Eur J Clin Micriobiol Infect Dis 2001; 20: 389-91. [CrossRef]

9. Haque R, Mondal D, Kirkpatrick BD, Akther S, Farr BM, Sack RB, et al. Epidemiologic and clinical characteristics of acute diarrhea with emphasis on Entamoeba histolytica infections in preschool children in an urban slum of Dhaka, Bangladesh. Am J Trop Med Hyg 2003; 69: 398-405.

10. Stauffer W, Abd-Alla M, Ravdin JI. Prevalence and incidence of Entamoeba histolytica infection in South Africa and Egypt. Arch Med Res 2006; 37: 266-9. [CrossRef]

11. Atas AD, Alim A, Atas M. Distribution of intestinal parasites in patients presenting at the Environmental- Food and Medicine Analysis Laboratory of Sivas Municipality during the Years 19932006. Turkiye Parazitol Derg 2008; 32: 59-64.

12. Malatyali E, Ozcelik S, Celiksoz A, Degerli S, Yildirim D. The Frequency of intestinal Parasites in Primary School Children in Urban and Rural Regions. Turkiye Parazitol Derg 2008; 32: 54-8.

13. Ok UZ, Girginkardesler N, Kilimcioglu A, Limoncu E, 1997. Dışkı İnceleme Yöntemleri. (Ed. Özcel MA, Altıntaş N). Parazit Hastalıklarında Tanı. Türkiye Parazitoloji Derneği, Ege Üniv. Basımevi, İzmir, s. 40-2.

14. Akarsu GA, Gungor C, Altıntas K. The prevalence of intestinal parasites in Ankara. Turkiye Parazitol Derg 2001; 25: 148-50.

15. Celik T, Daldal N, Karaman U, Aycan OM, Atambay M. Incidence of intestinal Parasites among primary school children in Malatya. Turkiye Parazitol Derg 2006; 30: 35-8.

16. Haque R, Ali IKM, Akther S, Petri WA. Comparison of PCR, isoenzyme analysis, and antigen detection for diagnosis of Entamoeba histolytica infection. J Clin Microbiol 1998; 36: 449-52.

17. Ravdin J. Amebiasis. Clin Inf Dis 1995; 20: 1453-66. [CrossRef]

18. World Health Organization. Amoebiasis. Report on the WHO/Pan American Health Organization/ UNESCO Expert Consultation, Mexico City. Wkly Epidemiol Rec 1997; 72: 97-100.

19. Haque R, Duggal P, Ali IKM, Hossain MB, Mondal D, Sack RB, et al Innate and acquired resistance to amebiasis in Bangladeshi children. $\mathrm{J}$ Infect Dis 2002; 186: 547-52. [CrossRef]

20. Mengeloglu FZ, Aktas E, Kulah C, Cömert Begendik F. Dışkı Örneklerinde ELISA Yöntemi ile Entamoeba histolytica'nın Saptanması. Turkiye Parasitol Derg 2009; 33: 1-3.

21. Sharma AK, Chibbar S, Bansal G, Kaur U, Vohra H. Evaluation of newer diagnostic methods for the detection and differentiation of Entamoeba histolytica in an endemic area. Transactions of the Royal Society of Tropical Medicine and Hygiene 2003; 97: 396-7. [CrossRef]

22. Delialioglu N, Aslan G, Sozen, M, Babur C, Kanık A, Emekdas G. Detection of Entamoeba histolytica/E.dispar in stool specimens by using ELISA. Mem Inst Oswaldo Cruz 2004; 99: 769-77. [CrossRef]

23. Tanyuksel M, Ulukanligil M, Guclu Z, Araz E, Koru O, Petri WA. Two cases of rarely recognized infection with Entamoeba moshkovskii. Am J Trop Med Hyg 2007; 76: 723-4.

24. Zeyrek F, Ozbilge H, Yuksel M, Zeyrek C, Sirmatel F. Parasitic fauna and the frequency of Entamoeba histolytica/Entamoeba dispar detected by ELISA in stool samples in Sanliurfa, Turkey. Turkiye Parazitol Derg 2006; 30: 95-8.

25. Sengupta K, Das P, Johnson TM, Chaudhuri PP, Das D, Nair GB. Production and characterization of monoclonal antibodies against a highly immunogenic fraction of Entamoeba histolytica (NIH:200) and their application in the detection of current amoebic infection. J Eukaryot Microbiol 1993; 40: 722-6. [CrossRef]

26. Mojarad EN, Haghighi A, Rad MA, Mesgarian F, Nejad MR, Zali MR. Prevalence of Entamoeba histolytica and Entamoeba dispar in Gonbad City, Iran. Iranian J Parasitol 2006; 2: 48-52.

27. Redondo RB, Mendez LGM, Baer G. Entamoeba histolytica and Entamoeba dispar: differentiation by Enzyme-Linked Immunosorbet Assay (ELISA) and its clinical correlation in pediatric patients. Parasitol Latinoam 2006; 61: 37-42.

28. El-Kadi MA, Dorrah AO, Shoukry NM. Patients with gastrointestinal complains due to enteric parasites, with reference to Entamoeba histolytica/dispar as detected by ELISA E. histolytica adhesion in stool. J Egypt Soc Parasitol 2006; 36: 53-64.

29. Haque R, Faruque ASG, Hahn P, Lyerly DM, Petri WA. Entamoeba histolytica and Entamoeba dispar infection in children in Bangladesh. J Infect Dis 1997: 175: 734-6. [CrossRef] 